\title{
Evaluation of Brain Death in Children in a Tertiary Pediatric Intensive Care Unit
}

\section{Üçüncü Basamak Pediatrik Yoğun Bakım Ünitesindeki Çocuklarda Beyin Ölümünün Değerlendirilmesi}

\author{
Süleyman Bayraktar ${ }^{1}$, (D) Bilge Tanyeri-Bayraktar², (D) Murat Elevli3 \\ ${ }^{1}$ University of Health Sciences Turkey, Haseki Training and Research Hospital, Clinic of Pediatric Intensive Care Unit, Istanbul, Turkey \\ ${ }^{2}$ Bezmialem Vakıf University Faculty of Medicine, Department of Neonatology, Istanbul, Turkey \\ ${ }^{3}$ University of Health Sciences Turkey, Haseki Training and Research Hospital, Clinic Pediatrics, Istanbul, Turkey
}

\begin{abstract}
Objective: This study aimed to evaluate the characteristics of children who are diagnosed with brain death (BD) in a tertiary care pediatric intensive care unit (PICU) and highlight the organ donation rates.

Methods: A retrospective observational study was conducted among pediatric patients who met the criteria of BD based on the medical records in all deaths that occurred between January 2018 and May 2021. The demographic data, main BD cause, duration between admission to PICU and $\mathrm{BD}$ decision, length of stay, time between $\mathrm{BD}$ decision and cardiac arrest, presence of apnea and ancillary tests, and organ donation status were recorded.

Results: This study analyzed 642 patients who are admitted to the PICU, wherein $1.9 \%$ was diagnosed as BD. Asphyxia was the most frequent cause of BD (33.3\%). The mean interval between the suspected of BD diagnosis and median of duration between BD decision and cardiac arrest were 18.58 \pm 13.77 ( $\min : 3$, max: 48) h and 36 (minimum (min): 1, maxsimum (max): 192) h, respectively. The mean length of stay in the PICU was $16.75 \pm 11.36$ days (min: 3 , max: 42). The disorders related to BD include diabetes insipidus (58.3\%) and hypothermia (33.3\%). Apnea test was positive in 6 (50\%) of 12 children. At least one ancillary test was used in all patients. Five of 12 (41.7\%) patients were not eligible for organ donation because they were refugee, and the families of the remaining 7 patients did not give permission for organ donation.

Conclusion: Organ donation can be increased if frequent family meetings are held by an experienced and trained team coordinator, including psychologists and religious authorities. This issue can be organized as a certified and standardized program throughout the country.
\end{abstract}

Keywords: Brain death, children, pediatric intensive care unit, organ donation, refugee

\section{öz}

Amaç: Üçüncü basamak çocuk yoğun bakım ünitesinde (YBÜ) beyin ölümü (BÖ) tanısı alan çocukların özelliklerini değerlendirmek ve organ bağışı oranlarına vurgu yapmak.

Gereç ve Yöntem: Ocak 2018-Mayıs 2021 tarihleri arasında meydana gelen tüm ölümlere ilişkin tıbbi kayıtlara dayanarak, BÖ kriterlerini karşılayan çocuk hastalarda geriye dönük gözlemsel bir çalışma yapılmıştır. Demografik veriler, BÖ’nün ana nedeni, çocuk YBÜ'ne kabul ve BÖ kararı arasındaki süre, hastanede kalış süresi, BÖ kararı ile kardiyak arrest arasındaki süre, apne testi ve yardımcı testlerin varlı̆̆ı, organ bağış durumu kaydedildi.

Bulgular: Çocuk YBÜ'ye başvuran toplam 642 hastanın \%1,9'u BÖ tanısı aldı. BÖ’nün en sık nedeni asfiksi idi (\%33,3). BÖ şüphesi ve BÖ tanısı arasındaki sürenin ortalama değeri ve BÖ tanısından sonra kardiyak arrestin meydana gelmesi arasındaki sürenin ortanca değerleri sırasıyla

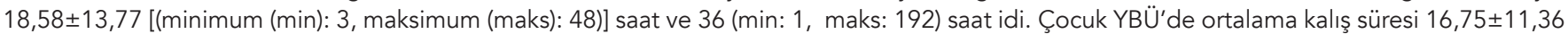
gün (min: 3, maks: 42) idi. BÖ'ye bağlı bozukluklar diabetes insipidus $(\% 58,3)$ ve hipotermi $(\% 33,3)$ idi. Oniki çocuğun 6'sında $(\% 50)$ apne testi pozitifti. Tüm hastalarda en az bir yardımcı test kullanıldı. On iki hastadan 5'i $(\% 41,7)$ mülteci oldukları için organ bağışına uygun bulunmadı, kalan 7 hastanın aileleri ise organ bağışına izin vermedi.

Address for Correspondence: Süleyman Bayraktar, University of Health Sciences Turkey, Haseki Training and Research Hospital, Clinic of Pediatric Intensive Care Unit, Istanbul, Turkey

Phone: +90 5323851078 E-mail: bsuleyman@hotmail.com ORCID ID: orcid.org/0000-0002-8080-2438

Cite as: Bayraktar S, Tanyeri-Bayraktar B, Elevli M. Evaluation of Brain Death in Children in a Tertiary Pediatric Intensive Care Unit.

Med J Bakirkoy 2021;17:425-431

Received: 09.10.2021

Accepted: 17.11 .2021 
Sonuç: Psikologlar ve dini otoritelerin de dahil olduğu, deneyimli ve eğitimli bir koordinatör ekip tarafından, sık sık aile toplantıları yapılırsa organ bağışı artırılabilir. Bu konu ülke genelinde sertifikalı ve standartlaştırılmış bir program olarak düzenlenebilir.

Anahtar Kelimeler: Beyin ölümü, çocuklar, çocuk yoğun bakım ünitesi, organ bağışı, göçmen

\section{INTRODUCTION}

Brain death $(\mathrm{BD})$ is a clinical diagnosis that is characterized by the complete, permanent, and irreversible loss of all brain, brainstem, and cerebellar activities (1-3). According to the Turkish Neurological Society, BD is described as "whole BD" that refers to the medical death state (4). The pathophysiologic features of BD include increased intracranial pressure, disrupted cerebral blood flow, and occluded cerebral perfusion $(1,3)$.

The American Academy of Pediatrics, the Child Neurology Society, and the Society of Critical Care Medicine published the $\mathrm{BD}$ guidelines in children $(5,6)$. Due to insufficient globally accepted definition and formal declaration guidelines, avoidance, and concerns continue in BD decisions in the pediatric intensive care units (PICU) (7). However, as access to critical care increases, more practitioners encounter this difficult clinical scenario (8). In this setting, the incidence of reported $B D$ varies. The reported rates of $B D$ are found in a wide range (10.8\%-37\%) in different pediatric studies (9-14).

Early diagnosis of $\mathrm{BD}$ is crucial for organ and tissue protection from cardiovascular and metabolic changes for organ donors $(3,11)$. Turkey was one of the first countries to legally establish the guidelines of BD; however, approximately 11,932 patients are waiting for organ transplantation and $5 \%-13 \%$ of them are pediatric patients (15).

Today, studies that conducted diagnosis of $\mathrm{BD}$ and the subsequent processes in children are limited. Thus, this study aimed to analyze the characteristics of children who are diagnosed with $\mathrm{BD}$ and highlight the organ donation rates in the PICU.

\section{METHODS}

\section{Study Design}

This retrospective observational study was conducted among pediatric patients who met the criteria for $\mathrm{BD}$ between January 2018 and May 2021. The pediatric ICU at University of Health Sciences Turkey, Haseki Training and Research Hospital is a tertiary care facility that is located in a low socioeconomic and cosmopolitan place of Istanbul. While our unit has 6 beds until April 2019, it has been increased to 10 beds after this date.

\section{BD Evaluation Policy}

Declaration of $\mathrm{BD}$ in pediatric cases is a special issue in Turkey, as well as worldwide (16). According to the
Regulations on Organ and Tissue Transplantation Services (17) in Turkey, the process in pediatric cases is as follows: a clinical BD finding should be established to fulfill the nonreversibility criteria. At the end of the waiting period, a second examination is required to confirm the unchanged clinical BD findings and a single apnea test is sufficient for diagnosis during this process.

The waiting period is $48 \mathrm{~h}$ in infants up to 2 months old, $24 \mathrm{~h}$ between 2 months and 1 year old, $12 \mathrm{~h}$ in $>1$ year, and $24 \mathrm{~h}$ in anoxic BD. Therefore, experienced pediatric radiologists who can perform and evaluate tests that show cerebral blood flow can facilitate a faster BD diagnosis without waiting for re-examination of brain stem reflexes (4). The guideline on BD that was published by the Turkish Neurological Association stated that at least two confirmatory tests in the newborn group (up to 2 months) and one laboratory test in children aged $>2$ months are required (4).

The decision of $\mathrm{BD}$ was taken with the judgment of two physicians following the Turkish BD regulation (16).

\section{Apnea Test}

The apnea test objectively measures the brainstem function without the respiratory drive that support BD declaration (18). Apnea testing standards also differ among countries, both in duration (5 to $15 \mathrm{~min}$ ) and interpretation of objective arterial blood gases (no pH guidelines for $<7.4)(13,18)$.

The apnea test was performed by a pediatric intensivist in the PICU and was interpreted as the absence of spontaneous breathing with partial pressure of carbon dioxide $\left(\mathrm{PaCO}_{2}\right)$ of $>60 \mathrm{mmHg}$ (or a $20 \mathrm{mmHg}$ increase in $\mathrm{PaCO}_{2}$ over the normal $\mathrm{PaCO}_{2}$ baseline) and the corresponding decrease in $\mathrm{pH}$ before buffering mechanisms can occur. Without observed respiratory efforts during the test, the apnea test demonstrates an insufficient drive to breathe, hence absence of function of the medullary respiratory centers. In the presence of hypoxia or hypotension during the testing, which makes the test invalid, the test should be stopped and the hypoxia or hypotension should be corrected (13).

\section{Ancillary Tests}

Uncompleted clinical examination or the apnea test, concerns about the validity of clinical findings, and desire to shorten the observation period between examinations are the indications of using ancillary tests (19). Ancillary tests assess for brain function [electroencephalogram (EEG)] or cerebral blood flow (radionuclide imaging, angiography, 
etc.) in the BD diagnosis (18). The term "ancillary" is preferred to "confirmatory," nevertheless, they can assist the clinician in BD diagnosis. Generally, ancillary tests are mandatory in $\mathrm{BD}$ diagnosis in some countries (10). Ancillary tests that are used in our hospital were EEG, computed tomography angiography (CTA), and transcranial Doppler sonography (TDS).

\section{Declaration of BD to the Family}

As soon as the diagnosis is made, BD declaration should be announced to the family and the organ transplant coordinator should be notified. These procedures were applied for all cases in the present study. According to the relevant law, BD was firstly declared to parents by the PICU team. After that, the hospital's local organ transplant coordinator interviews the families for organ donation.

\section{Ethical Approval and Data Selection}

The Local Ethical Board of University of Health Sciences Turkey, Haseki Training and Research Hospital approved the study (approval no: 61-2021 date: 14.07.2021).

The medical records of patients were accessed using the hospital database. The following demographics were recorded: age at diagnosis, sex, main $\mathrm{BD}$ cause, and duration between admission to PICU and BD decision, length of stay, interval between BD decision and cardiac arrest, and organ donation status.

The main cause to BD was grouped into the following categories: Multiple trauma, central nervous system (CNS) infection, hypoxia/asphyxia (status epilepticus, following cardiopulmonary arrest, sudden death, etc.), stroke, and CNS tumor.

Alterations accompanying to BD were analyzed, such as diabetes insipidus, hypothermia, hyperglycemia, coagulopathy, and hemodynamic instability.

Diabetes insipidus: Polyuria (urine output of $>4 \mathrm{~mL} / \mathrm{kg} / \mathrm{h}$ for children and $300 \mathrm{~mL} / \mathrm{h}$ for children $>70 \mathrm{~kg}$ ), urine density of $<1.005$, high serum osmolality $(>300 \mathrm{mOsm} / \mathrm{kg}$ ) and low urine osmolality $(<300 \mathrm{mOsm} / \mathrm{kg})$ at the time of diagnosis, and hypernatremia with $\mathrm{Na}$ of $>145 \mathrm{mEq} / \mathrm{dL}$.

Hypothermia: Core temperature of $<35^{\circ} \mathrm{C}$

Hyperglycemia: Blood glucose of $>180 \mathrm{mg} / \mathrm{dL}$

Coagulopathy: Prothrombin time of $<60 \%$

Hemodynamic dysfunction: Mean blood pressure of $<2$ standard deviations (SD) from the $50^{\text {th }}$ percentile for the age and/or inotrope or vasopressor requirements or increased dosage
All patients were eligible for organ donation; however, five of them were refugees.

\section{Statistical Analysis}

The results were analyzed using the Statistical Package for the Social Sciences statistical software program (version 18.0, SPSS Inc. IBM Corp., Armonk, NY, USA). Descriptive statistics were expressed as frequency and percentage values for categorical variables and mean $\pm S D$ (min, max) for continuous variables. If the measured outcome distribution based is abnormal, values were expressed as median and interquartile range.

\section{RESULTS}

Totally, 642 patients were followed up in the PICU, where 50 (7.8\%) died. Of the 50, 12 (24.0\%) were diagnosed with BD. Of all PICU admissions, $1.9 \%$ were diagnosed with BD. The demographic and clinical findings were presented in Table 1. The mean age of patients was $6.7 \pm 3.8$ years [minimum (min): 4 months, maksimum (maks): 11.5 years]. Of the children, $58.3 \%(n=7)$ were girls. The causes of BD were listed as asphyxia in 4 (33.3\%), CNS tumor in $3(25.0 \%)$, CNS infections in $3(25.0 \%)$, and trauma in 2 (16.7\%) patients. The suspected of $\mathrm{BD}$ to $\mathrm{BD}$ diagnosis and the median duration of cardiac arrest after diagnosis were 18.58 \pm 13.77 ( $\mathrm{min}: 3$, max: 48) $h$ and 36 (min: 1, max: 192) h, respectively. The mean length of stay in the PICU was $16.75 \pm 11.36$ days (min: 3, max: 42). The disorders related to BD include diabetes insipidus (58.3\%) and hypothermia (33.3\%). Apnea test was positive in $6(50 \%)$ of 12 children. During apnea test one patient had pneumothorax. Eight (66.7\%) children were followed with EEG, which revealed isoelectrical activity. Ten (83.3\%) children had CTA and only 2 (16.7\%) patients had TDS. Both the ancillary tests were compatible with BD. All cases were suitable for organ donation. Since 5 patients are refugees, they were accepted as unsuitable for organ donation. The families refused organ transplantation in 7 patients. The main reasons for the rejection of organ donation were religious beliefs in 5 (71.4\%) families and the inability to accept the beating of the heart as dead in 2 (28.6\%) families.

\section{DISCUSSION}

This retrospective study found the rate of $\mathrm{BD}$ as $24.0 \%$ among patients who died in the PICU, and suitable donors were found for organ donation; however, no family consent could be obtained.

Bonetto et al. (10) reported the overall mortality as $7.45 \%$ and $\mathrm{BD}$ as $19.14 \%$. Kirschen et al. (9) declared the rate of 
Table 1. Demographic and clinical features of children diagnosed with BD

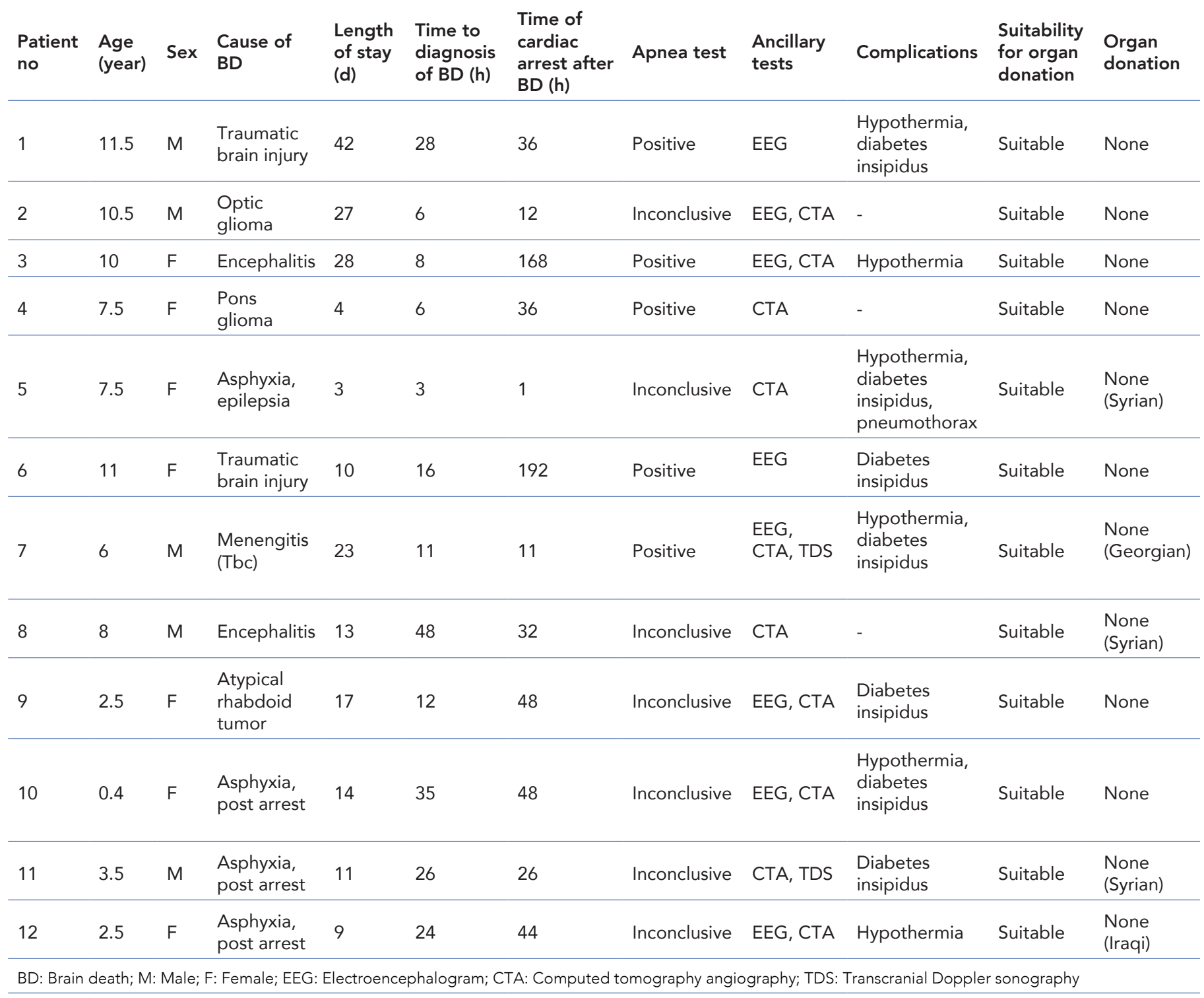

BD as $20.7 \%$. The crude rate of BD was $1.1 \%$ in the PICU from our country (20). Sucu et al. (1) noticed the mortality as $10.2 \%$ and the BD as $17 \%$ of these patients. Yener et al. (11) mentioned $10.8 \%$ of deaths as BD. Our BD percentage was found to be similar to the previous studies.

A study conducted in children revealed the average age as $6.8 \pm 5.5$ years (21). Kirschen et al. (9) reported that the age of patients in this group was between 2 and 12 years. The mean age of children in our study was consistent with the study of Özmert et al. (21).

The major disease that causes BD varied in studies. The most common causes of BD include hypoxic-ischemic injury, shock, and/or respiratory arrest, and traumatic brain injury $(9,12,22)$. Some studies have classified the common diseases of BD according to the age of children. Multiple trauma was found as the main cause at median 7 years old (10), whereas traumatic brain injury was the leading cause of $\mathrm{BD}$ in children over 1 year old in developed countries, and no clear data is reported on this subject in our country (1). Trauma and intracranial hemorrhage were found as the highest rate in patients who are diagnosed with BD in some studies $(2,6,21)$. A study conducted in our country revealed that traumatic brain injury was the leading cause in $70 \%$ of patients (20). Thus, Sucu et al. (1) stated that traumatic brain injury was a cause at a rate of $7 \%$. Contrarily, Yener et al. (11) found post-cardiorespiratory arrest as a common cause of BD. Our study found that the most common reason was asphyxia (33.3\%) and the diagnosis of patients at admission 
varied in a large spectrum.

Early recognition of BD in hospital follow-up is important in evaluating the patients for organ donation (23). The mean time to diagnosis after BD suspicion was $5.9 \pm 6.2$ days in a study by Özmert et al. (21), whereas another study mentioned 3 days (24). Karasu et al. (25) reported that these periods were 6.8 days in patients aged 18 years. Additionally, Altınsoy et al. (26) compared two different time periods and found that duration of BD diagnosis shortened over the years. In previous studies, the time of BD diagnosis was not found to be different in children compared with adults. Our study revealed that the time of diagnosis was 18.58 hours, which was shorter than the reported studies because of not waiting for the second examination.

The studies also reported the interval from BD diagnosis to cardiac death, which revealed 6.8 days in patients younger than 18 years of age and 2.5 days in patients aged 18 years and older (25) since the time for cardiac death lasts longer than expected because physicians tend to continue life support both for cultural reasons, while getting the decision of $\mathrm{BD}$ from the families and change their minds for organ donation idea (27). The mean time to develop cardiac arrest after the diagnosis of $\mathrm{BD}$ was $6.9 \pm 7.4$ days in non-donor cases whose medical support had been reduced (21). The duration of cardiac arrest after diagnosis was similar in both children (3.63 \pm 4.93 days) and adults (2.17 \pm 2.31 days) (26). Our study revealed that the median interval between $B D$ and cardiac arrest was $36 \mathrm{~h}$.

The most common alterations reported in studies include hypothermia, diabetes insipidus, and hemodynamic dysfunction $(10,11,21)$. Antidiuretic hormone deficiency occurs in $65 \%-90 \%$ of patients with $\mathrm{BD}$ due to neurohypophysis damage (20). Bonetto et al. (10) also found hemodynamic dysfunction (63.2\%) and diabetes insipidus (46.6\%) in their study. A careful organ preservation treatment protocol in intensive care is the first step in successful organ transplantation. Therefore, knowing and addressing the mechanisms of complications is important (21). In our patients, hypothermia and diabetes insipidus were obtained in accordance with the literature.

Apnea test is mandatory in BD diagnosis in Turkey; however, Sucu et al. (1) found positive apnea test in $36 \%$ of patients. Our study applied the apnea test to all of patients, but was terminated due to complications (hypoxia, hypotension, etc.) in $50 \%$. Positive apnea test was found higher in our study than the study of Sucu et al. (1). The reasons behind low apnea testing in some countries are as follows: 1. It is invasive and risky 2. Obtaining consent form from the guardians is difficult (7). Our country does not mandate taking a consent form for an apnea testing. During the apnea test, serious complications (cardiac arrest, hypotension, hypoxemia, and pneumothorax) may occur $(28,29)$. One patient had pneumothorax during the apnea test.

The clinical evaluation is prioritized over the ancillary tests according to the pediatric BD guidelines that was revised in 2011, but a variety of ancillary tests are currently used in clinical practice $(10,19,29)$. Studies showed that healthcare professionals used more ancillary tests in pediatric patients than in adults (19). The idea behind this behavior may be an attempt to objectively demonstrate the absence of cerebral blood flow or electrical brain function, rather than findings that appear subjective on clinical examination (19). BD declaration using ancillary methods is mandatory in Argentina (10). The consequences of adopting a health policy in the mandatory ancillary methods are based on the ethical and cultural conditions specific to each country. A study conducted in our country revealed that $76.2 \%$ of patients needed ancillary tests, the most common was CTA (22.4\%) and mentioned that the need for ancillary tests declined throughout the years because of awareness and clinical experience of involved physicians (27). Özmert et al. (21) reported that EEG was performed in $61 \%$ of patients in addition to the apnea test. They used radiological imaging methods in 39\% of patients (21). Another study by Altınsoy et al. (26) used DSA to support the diagnosis of $\mathrm{BD}$ and mentioned that DSA was the gold standard in BD diagnosis and might contribute to shortening the diagnosis period (26). Karasu et al. (25) showed that $30.4 \%$ of BD cases needed ancillary tests for diagnosis. In our study, the ratio of the ancillary tests performed seemed higher than the other studies to convince the families in BD decision. In our hospital region, the educational level of population is low, thus they rely on sophisticated diagnostic tools. They have no idea about BD. The term BD is a traumatic diagnosis for families who face it for the first time in their lives. BD is often confused with the diagnosis of vegetative life. Socio-cultural structure, religious beliefs, influence of family elders, and being a refugee are the factors effecting family reactions. Efforts should be made to improve the society's understanding of $\mathrm{BD}$ and to improve physician practices in determining $B D$ (19). However, the diagnosis and process of $B D$ is difficult in pediatric patients, especially in patients with hemodynamic disorders, thus physicians may act more cautiously.

In the field of pediatrics, the need for solid organ donations has increased worldwide, $1.5 \%-2 \%$ patients were in the waiting list of developed countries (21). Organ donation rate was found in 43.8 people per million in Spain (30). A 
retrospective adult study in Qatar reported the rate of family rejection as $93 \%$. This result was attributed to various factors, such as religious beliefs, culture, population dynamics (high number of immigrants), and ignorance of the importance of organ donation (31). Another study included 268 patients with a family approval rate of $78.4 \%$ and the organ donation approval rate rose with the increased frequency of meetings held by an organ transplantation coordinator with the family after BD declaration (32). Organ transplant centers and physicians in our country are adequately equipped; however, the number of organ donations is insufficient. The trained physicians, standardization of BD protocols, use of a checklist, and frequent meetings with families using precise, consistent, and clear language are important to ensure the integrity of BD determination and organ donation $(9,32)$. Battal et al. (24) found the rate of organ donation as $29.03 \%$ in their study, whereas other studies reported 17\%-34.2\% $(21,25,27)$. The rate of organ donation is still less than expected, and many patients are on transplant waiting lists (27). A study conducted in PICU revealed that no donor was issued like our study (1). Previous studies stated that the most serious problem regarding organ donation in Turkey was the death of patients without BD diagnosis and the lack of organ transplant coordinators (2). Recently, the use of international guidelines and the organization of the intensive care team enabled early BD diagnosis, but the organ donation rate is still low. When interviewed with the families of organ donors, Kıraklı et al. (33) reported that 36\% of them seemed previously positive, and $64 \%$ attributed this to the influence of the coordinator. Altınsoy et al. (26) revealed that the rate of organ donation was $37.87 \%$ before 2014 and $21.15 \%$ after 2014. They commented that this difference may be due not only to be social characteristics of the guardian of patients but also to the communication skills of the employees in the organ donation coordination unit (26). Therefore, organ transplant coordinators, who will receive family approval, should be trained and experienced. Family interviews that are conducted by an experienced and trained transplant coordinator should emphasize that $\mathrm{BD}$ is a real death and organ donation is important. Religious, cultural, and legal reasons and the lack of adequate infrastructure and resources are the main reasons behind the continuation of life-saving and life-improving treatment and rejection of organ donation. Some physicians reported that it is commonly requested to continue organ support because of the belief that a patient who is declared BD can regain neurological function or a lack of acceptance that a person can be dead if the heart was still beating (9). Another obstacle to organ donation in our study was being a refugee. According to the organ transplant regulation, the inability to receive organ donations from refugees reduces the rate of organ transplants, as seen in our study.

\section{Study Limitations}

The study was conducted in a retrospective design. The results are from a single center of 10-bed PICU, thus the size of the study may be too small.

\section{CONCLUSION}

Families should be informed that BD is considered a definite death and that organ donation is important. In this respect, the importance of informing the public, regularly through the media, and social media was emphasized. Having a psychologist who is experienced as an organ donation coordinator and can properly communicate with families will increase the rate of organ donation. The donation rate is believed to increase if family meetings are frequently held by an experienced and trained coordinator team including religious authorities. This issue can be organized as a certified and standardized program throughout the country. Shortly, organ donation rates can be increased by designing the regulations about refugees becoming organ donors.

\section{ETHICS}

Ethics Committee Approval: The Local Ethical Board of University of Health Sciences Turkey, Haseki Training and Research Hospital approved the study (approval no: 612021 date: 14.07.2021).

Informed Consent: This study is retrospective.

\section{Authorship Contributions}

Surgical and Medical Practices: S.B., M.E., Concept: S.B., B.T.B., Design: S.B., B.T.B., Data Collection or Processing: S.B., Analysis or Interpretation: S.B., B.T.B., M.E., Literature Search: S.B., B.T.B., Writing: S.B., B.T.B., M.E.

Conflict of Interest: No conflict of interest was declared by the authors.

Financial Disclosure: The authors declared that this study received no financial support.

\section{REFERENCES}

1. Sucu A, Tolunay O, Çelik T, Kahveci B, Celiloğlu C, Özdemir U, et al. Evaluation of Patients Diagnosed with Brain Death in Pediatric Critical Care. J Pediatr Emerg Intensive Care Med 2018;5:59-63.

2. Atik B, Kılınç G, Atsal AÖ, Çöken F, Yarar V. Our Brain Death and Organ Donation Experience: Over 12 Years. Transplant Proc 2019;51:2183-5.

3. Anıl AB, Anıl M, Yavaşcan Ö, Kanar B, Aksu N. Brain Death and Organ Transplantation in Children: A Case Report. Journal of Child 2009;9:195-8. 
4. Turkish Neurological Society - Diagnostic Guidelines for Brain Death. Turk J Neurol. 2014;20:101-4.

5. Nakagawa TA, Ashwal S, Mathur M, Mysore M; Society of Critical Care Medicine, Section on Critical Care and Section on Neurology of American Academy of Pediatrics; Child Neurology Society. Clinical report-guidelines for the determination of brain death in infants and children: an update of the 1987 task force recommendations. Pediatrics 2011;128:720-40.

6. Mathur M, Ashwal S. Pediatric brain death determination. Semin Neurol 2015;35:116-24.

7. Araki T, Yokota H, Fuse A. Brain Death in Pediatric Patients in Japan: Diagnosis and Unresolved Issues. Neurol Med Chir (Tokyo) 2016;56:1-8.

8. Wooldridge G, Fonseca Y. Confirming Pediatric Brain Death in resource-limited settings: Lessons and challanges. Pediatr Neurol 2020;111:85-6.

9. Kirschen MP, Francoeur C, Murphy M, TraynorD, Zhang B, Mensinger $\mathrm{JL}$, et al. Epidemiology of Brain Death in Pediatric Intensive Care Units in the United States. JAMA Pediatr 2019;173:469-76.

10. Bonetto G, Taffarel P, Gamerman M, Jorro Barón F, Gaviña C, Flores $L$, et al. Brain death and organ donation in Argentine pediatric intensive care units. A multicenter study. Arch Argent Pediatr 2018;116:54-60.

11. Yener N, Paksu MŞ, Köksoy Ö. Brain Death in Children: Incidence, Donation Rates, and the Occurrence of Central Diabetes Insipidus. J Crit Care Med (Targu Mures) 2018;4:12-6.

12. Lago PM, Piva J, Garcia PC, Roster E, Bousso A, Sarno MO, et al. Brain death: medical management in seven Brazilian pediatric intensive care units. J Pediatr (Rio J) 2007;83:133-40.

13. Joffe AR, Shemie SD, Farrell C, Hutchison J, McCarthy-Tamblyn L. Brain death in Canadian PICUs: demographics, timing, and irreversibility. Pediatr Crit Care Med 2013;14:1-9.

14. Goh AY, Mok $Q$. Clinical course and determination of brainstem death in a children's hospital. Acta Paediatr 2004;93:47-52.

15. Gündüz RC, Şahin Ş, Uysal-Yazıcı M, Ayar G, Yakut Hi, Akman AÖ, et al. Brain death and organ donation of children. Turk J Pediatr 2014;56:597-603.

16. Sağlık bakanlığı ve bağlı kuruluşların teşkilat ve görevleri hakkında kanun hükmünde kararname ile bazı konularda değişiklik yapılmasına dair kanun. 2014. Available from: http://www. resmigazete.gov. tr/eskiler/2014/01/20140118-1.htm (accessed 27.1.2014 2014) 6 .

17. Organ ve Doku Alınması Saklanması ve Nakli Hakkında Kanun (29.05.1979 Sayısı: 2238 R.G. Tarihi: 03.06.1979 R.G. Sayısı: 16655), 1979. Available from: http://www.saglik. gov.tr/TR/belge/1-445/ tarihi29051979-sayisi2238-rg-tarihi03061979-rg-sayis-html (accessed 22.12.2013 2013).

18. Rayner M, Mansoor M, Holt T, Hansen G. Brain Death Criteria: Medical Dogma and Outliers. Yale J Biol Med 2019;92:751-5.
19. Lewis A, Adams N, Chopra A, Kirschen MP. Use of Ancillary Tests When Determining Brain Death in Pediatric Patients in the United States. J Child Neurol 2017;32:975-80.

20. Öztürk NY, İnceköy Girgin F, Birtan D, Cinel İ. Exploring brain death at a tertiary pediatric intensive care unit in Turkey; Incidance, etiology and organ donation. J Pediatr Emerg Intensive Care Med. 2016;3:11-4.

21. Özmert S, Sever F, Ayar G, Yazıcı MU, Öztaş DK. Brain Death and Organ Donation in Paediatric Intensive Care Unit. Turk J Anaesthesiol Reanim 2019;47:55-61.

22. Gotay-Cruz F, Fernández-Sein A. Pediatric experience with brain death determination. P R Health Sci J 2002;21:11-5.

23. Gómez MP, Arredondo E, Páez G, Manyalich M. International registry in organ donation and transplantation 2010. Transplant Proc 2012;44:1592-7.

24. Battal M, Horoz A, Karatepe O, Çitgez B. Experience of research hospital in determination of brain death. Med Bull Sisli Etfal Hosp 2013;47:59-62.

25. Karasu D, Yılmaz C, Karaduman I, Çınar YS, Büyükkoyuncu Pekel N. Retrospective Analysis of Patients with Brain Death. J Crit Intensive Care 2015;6: 23-6.

26. Altınsoy S, Özdemir EŞ, Baran I, Akelma FK, Arslan MT, Ergil J. Evaluation of Patients with Brain Death Diagnosis and Investigation of the Effect of New Regulation on the Duration of Diagnosis. J Turk Intens Care 2020;18:21-7.

27. Mutlu NM, Peker TT, Acar S, Koca B, Soyal ÖB, Titiz AP, et al. Brain Deaths and Donors in an Education and Research Hospital. Transplant Proc 2019;51:2176-9.

28. Thery G, Rosman J, Julien G, Chaix F, Mateu P. Brain death: Bilateral pneumothorax and pneumoperitoneum after an apnoea test. Anaesth Crit Care Pain Med 2019;38:89-90.

29. Monteiro LM, Bollen CW, van Huffelen AC, Ackerstaff RG, Jansen NJ, van Vught AJ. Transcranial Doppler ultrasonography to confirm brain death: a meta-analysis. Intensive Care Med 2006;32:1937-44.

30. Statista. Rates of deceased organ donors in select countries in 2017 (per million population). 2017. accessed, https://www.statista. com/ statistics/406893/rate-of-organ-donation-by-deceased-donorsinselect-countries

31. George S, Thomas M, Ibrahim WH, Abdussalam A, Chandra P, Ali $H S$, et al. Somatic survival and organ donation among brain-dead patients in the state of Qatar. BMC Neurol 2016;16:207-11.

32. Frutos MA, Blanca JM, Mansilla JJ, Rando B, Ruiz P, Guerrero F, et al. Organ donation: a comparison of donating and nondonating families. Transplant Proc 2005;37:1557-9.

33. Kıraklı C, Uçar ZZ, Anıl AB, Özbek I. The effect of shortening confirmed brain death diagnosis time on organ donation rates in the intensive care unit. J Crit Intensive Care 2011;1:8-11. 